\title{
ORGANISATIE VAN DEN GENEESKUNDIGEN DIENST IN SURINAME
}

\author{
DOOR \\ C. BONNE
}

Eenige jaren geleden was de Chef van het Militair Hospitaal in Paramaribo tevens Geneeskundig Inspecteur. Als Chef van het Mil. Hospitaal komt uit een Officier van Gezondheid, die geoordeeld wordt een goed hospitaalchef te zijn. Maar een Geneeskundig Inspecteur in een land als Suriname moet zijn een hygiënist. Als regel was de chef van het hospitaal dit niet. De samenkoppeling van beide ambten gaf opeenhooping van werk en daarom gingen reeds sinds langen tijd stemmen op, de betrekkingen te scheiden. Ook andere motieven golden daarvoor, maar op bovengenoemde reden werd de meeste nadruk gelegd. Inderdaad was de samenvoeging ongewenscht. De leiding van een groot hospitaal eischt den geheelen mensch; niet minder geldt dit voor het ambt van Geneeskundig Inspecteur. De gewenschte scheiding kwam, maar bracht consequenties, waaraan men in het ijveren voor de scheiding weinig aandacht had geschonken. Niet alleen de ambten werden gescheiden, maar de diensten werden in hun geheel gescheiden en er kwamen twee geheel zelfstandige geneeskundige diensten, de z.g. Militaire en de Burgerlijke geneeskundige dienst. Dit zou niet gehinderd hebben als de militaire geneeskundige dienst werkelijk een geneeskundige dienst onder militairen was. Maar dat is hij geenszins. Het militaire element is maar een onbeduidend onderdeel, in hoofdzaak is de militaire geneeskundige dienst de dienst in het zoogenaamd Militair Hospitaal en dit is een verplegingsinrichting voor burgerlijke personen met ook enkele militairen. De scheiding schiep dus in wezen twee 
burgerlijke geneeskundige organisaties, die niets met elkaar hebben uit te staan, een in het hospitaal en een voor den medisch-hygiënischen dienst daarbuiten. Dit is mijns inziens een kardinale fout in den opzet van den burgerlijken geneeskundigen dienst in Suriname. De geneeskundig Inspecteur, die hoofd van den burgerlijken geneeskundigen dienst wordt genoemd en dus de verantwoordelijke persoon is voor den gezondheidstoestand in de kolonie, heeft geen invloed in het grootste hospitaal van Suriname. De chef van het hospitaal kan hem daar dulden, maar kan hem bij wijze van spreken ieder oogenblik buiten de deur laten zetten, als hij te lastig wordt. Dit is een onhoudbare toestand, die op den duur nooit bestendigd kan blijven. Zelfs indien geneeskundig inspecteur en chef van het hospitaal de beste vrienden zijn zullen zij nu en dan in botsing komen. „Er kunnen geen twee groote masten staan op een schip", zegt een oud Hollandsch spreekwoord en er kunnen geen twee opperbevelhebbers zijn in onzen modernen tijd, zelfs niet onder geallieerden in den strijd. Het z.g. militair hospitaal in Paramaribo moet de kern zijn van den burgerlijken geneeskundigen dienst in Suriname. Van alle oorden stroomen hier de patiënten binnen. Nergens zijn beter gegevens te verzamelen betreffende den gezondheidstoestand in verschillende gedeelten van de kolonie dan juist in het hospitaal. De geneeskundig inspecteur moet, geheel naar eigen inzicht, deze bron van informaties zich systematisch ten nutte maken. Stads- en districts geneesheeren, zijn „Sanitary Inspectors”, als die er komen, en het hospitaal in Paramaribo moeten hem de gegevens verschaffen voor zijn werk. En de gegevens uit het hospitaal zijn de belangrijkste, omdat daar de ziekten met alle hospitaal- en laboratorium hulpmiddelen zooveel nauwkeuriger kunnen worden herkend dan daarbuiten. Een zelfstandig chef van het hospitaal kan die nooit zoo verschaffen, als de geneeskundig Inspecteur dit wenscht, tenzij hij zich geheel richt naar de inzichten van den geneeskundig inspecteur, maar dan is hij niet zelfstandig meer. De chef van het Militair Hospitaal heeft geheel andere dingen aan het hoofd dan de muizenissen van den ge- 
neeskundig inspecteur; wat voor den geneeskundig inspecteur zeer belangrijk kan zijn, is soms voor hem nauwelijks van beteekenis en ook omgekeerd.

Dit is slechts één zijde van het conflict. Bij de uitvoering van hygiënische maatregelen ontstaan dezelfde soort moeilijkheden. Indien de geneeskundig inspecteur het noodig vindt bepaalde personen te laten opnemen, bepaalde onderzoekingen te laten verrichten dan zal een zelfstandig chef van het hospitaal dit wel laten doen, als het hem gelegen komt en hij niet van meening omtrent de noodzakelijkheid van deze maatregelen met den geneeskundig inspecteur verschilt. Maar verschilt hij wel van meening en bemoeilijken deze maatregelen den gang van zaken in het hospitaal eenigszins, dan zal hij als onafhankelijk chef die maatregelen niet uityoeren, het is zelfs zijn plicht het niet te doen, want hij heeft in de eerste plaats te zorgen, dat alles in het hospitaal zoo vlot mogelijk loopt.

De geneeskundige school staat onder leiding van den geneeskundig inspecteur. Maar de inrichting tot opleiding is het z.g. Militair Hospitaal en slechts de chef van dit hospitaal kan kamers daarvoor afstaan en inrichten etc.

$\mathrm{Nu}$ zouden ten slotte door onderling overleg vele dingen te regelen zijn, vooropgesteld dat de beide personen goede vrienden met elkaar bleven. Maar het schijnt mij als hygiënist een onmogelijkheid toe, dat de geneeskundig inspecteur via den chef van het hospitaal zich geregeld die inlichtingen kan verschaffen betreffenden den gezondheidstoestand, die voor hem moeten zijn als dagelijksch brood. Dat onderdeel van zijn taak kan hij nooit uit handen geven, anders handelt hij als de soldaat, die op wacht staat en een ander op zijn post zet om te luisteren naar onraad.

Er zijn andere bezwaren van meer practischen aard tegen de volledige scheiding van hospitaal en burgerlijken geneeskundigen dienst; bijv. de hoogere kosten voortvloeiende uit dubbele bureaux, dubbele laboratoria, dubbele bibliotheek, dubbel corps van arbeiders en ambtenaren enz. Er zijn bezwaren van administratieven aard, maar ik heb het hygiënisch bezwaar op den voorgrond ge- 
plaatst, omdat dit voor den hygiënist het zwaarst weegt.

Wil ik nu daarmee betoogen, dat de oude toestand terug moet keeren? In het minst niet. Maar de geneeskundig inspecteur moet de vrije hand hebben in het z.g. Militair Hospitaal, daar kunnen nagaan en onderzoeken wat hij wil, daarin laten opnemen wat hij wil en dit kan alleen als hij invloed kan uitoefenen op den chef. Er moet mijns inziens blijven een chef van het hospitaal zooals die er thans is, belast met den dagelijkschen gang van zaken, zorg voor zieken en personeel, onderhoud en inrichten van gebouwen, maar die moet naar redelijkheid verplicht zijn den geneeskundig inspecteur ter zijde te staan met zijn geheele hospitaal-organisatie. Bestaat er niet een dergelijke verhouding tusschen het hoofd van het Landbouwdepartement en den chef van den Cultuurtuin? Nu zou zonder twijfel deze verhouding van het begin af ontstaan zijn als het Militair Hospitaal genoemd was, wat het ondanks alles in werkelijkheid toch is, een burgerlijk ziekenhuis.

Er zijn op den duur dan ook slechts twee dingen mogelijk, ò men valt terug in den ouden toestand dat de chef van het hospitaal, dus iemand, bij wien men als regelgeen recht heeft bijzondere kennis van hygiëne te verwachten, weer wordt geneeskundig inspecteur ò geleidelijk ontwikkelt zich de nieuwe zuiverder toestand en wordt het Militair Hospitaal een burgerlijke instelling, daardoor vanzelf komende onder controle van den geneeskundig inspecteur. Alleen in het bijzondere geval dat een officier van gezondheid-hygiënist beschikbaar was voor Suriname zou deze kunnen zijn hoofd van den Mil. geneeskundigen dienst met onder zich een chef van het hospitaal, terwijl hij zelf dan kon optreden als geneeskundig inspecteur en dan was de gewenschte verhouding tijdelijk ook bereikt.

Ten slotte wil ik besluiten met een aanhaling uit een publicatie van Prof. J. J. van Loghem „Vraagstukken der Indische Hygiëne" :

„Er bieden zich twee mogelijkheden aan wat de onderlinge verhouding van hygiëne en geneeskunde betreft. Men kan deze beiden gescheiden houden of in ééne hand 
brengen. Waar de geneeskundige factor van zoo groote beteekenis is voor de hygiëne verdient onder tropische omstandigheden een hygiënisch-geneeskundige dienst de voorkeur boven het gescheiden stelsel. Als voorbeeld van het eenheidsstelsel kan de organisatie van den gezondheidsdienst van het Panamakanaal worden aangehaald.

In steden ontmoet men vaak een praktisch bezwaar tegen den eenheidsdienst, omdat, voor men aan hygiëne denkt, er reeds een geneeskundige dienst bestaat, of eenige geneeskundige instellingen, die bij de aangeduide reorganisatie onder opperbeheer van iemand komen, wiens voornaamste bevoegdheid niet op geneeskundig doch op hygiënisch terrein ligt.

Toch gaat het die richting uit; in Europa kan men reeds getuige zijn van botsingen tusschen geneeskundige en hygiënische diensten, die het beste vermeden worden door beide diensten in eene hand te brengen.

Kiest men een andere oplossing, dan dient men den stadsgezondheidsdienst beschikking over eigen geneeskundige hulpmiddelen te geven. Reeds vroeger heb ik gewezen op de les der ervaring, dat een gezondheidsdienst over een eigen hospitaal voor besmettelijke ziekten moet beschikken. Afhankelijkheid van het inzicht van een anderen dienst belemmert den spoed der opneming, soms de opneming zelve. Aan den gezondheidsdienst moet in het belang van zijn taak geheel de vrije hand worden gelaten. Acht deze dienst op grond van epidemiologische exploratie ziektegevallen ,,verdacht”, dan behoort hij ook gelegenheid te hebben tot observatie, zonder het belemmerende medezeggenschap van een anderen dienst, die met den gedachtengang en de werkwijze van een hygiënischen dienst niet vertrouwd is. Men behoeft niet naar den evenaar te reizen om deze ervaring op te doen.

De uitvoering van de taak van een gezondheidsdienst is niet denkbaar zonder hulp van een wel ingericht laboratorium, waarover de chef volledige beschikking heeft zoowel ten behoeve van het routinewerk als van de exploratie. Ook in dit opzicht moet hij niet afhankelijk zijn van eens anders inzicht, omdat niemand beter dan hij zelf ge- 
294 ORGANISATIE VAN DEN GENEESK. DIENST ENZ.

oriënteerd kan zijn over de richting, waarin geëxploreerd moet worden."

Prof. van Loghem kon dit met het oog op Suriname hebben geschreven, zoo is het op de toestanden daar van toepassing. 